\title{
Recovery of a sewage sludge dumping ground. II. Macrobenthic community
}

\author{
D. C. Moore, G. K. Rodger \\ SOAFD Marine Laboratory, Victoria Road, Aberdeen AB9 8DB, Scotland
}

\begin{abstract}
Following cessation of sewage sludge disposal at a site ca $2 \mathrm{~km}$ from Garroch Head, Isle of Bute, Firth of Clyde (Scotland), a study of the recovery of the benthic environment was undertaken. In order to permit comparisons a reappraisal of data obtained in 1971, whilst the site was still actively in use, was undertaken. Based on the parameters used, the benthic community showed a marked recovery from its status in 1971 and now approaches what should be considered as normal for this slightly enriched area.
\end{abstract}

\section{INTRODUCTION}

Before using the sea for waste disposal its potential for recovery, particularly that of the benthic fauna, must be considered. Information on the recovery phase following sewage sludge disposal is limited to field investigations at a site off Philidelphia, USA (Devine \& Simpson 1985) and extrapolation from experimental studies (Eleftheriou et al. 1982). This paper reports investigations of the recovery of the benthic environment 11 yr after cessation of dumping of sewage sludge at an accumulating disposal site in the Firth of Clyde, Scotland

The dumping of wastes in Scottish waters is controlled under the Food and Environment Protection Act, Part II, 1987 (FEPA), formerly the Dumping at Sea Act, 1974 (DASA). A review of the practical approach taken to the assessment of applications to dispose of wastes in Scottish waters is given by Topping (1987). The legislation lays certain constraints on disposal operations, one of which is to specify the precise locations at which dumping is to take place. However, prior to the implementation of DASA this specification was not statutory and the location of the disposal operation was not well defined. Prior to 1974, the disposal operation in the Firth of Clyde was located in an area ca $4 \mathrm{~km}$ north of the present operation (Fig. 1). The site was situated in 70 to $80 \mathrm{~m}$ of water which has slow water currents ( $<10 \mathrm{~cm} \mathrm{~s}^{-1}$; Dooley 1979). This area received sewage sludge virtually continuously from 1904 to 1974, but not subsequently, as described by Harper \& Greer (1988).
Various studies (MacKay \& Topping 1970, Mackay et al. 1972, Topping \& McIntyre 1972, Halcrow et al. 1973) undertaken before 1974 on the effects of the dumping operation at the northern site (Site A) showed the classical effects of organic enrichment on the benthic fauna, i.e a decrease in species diversity and an increase in individual population abundance and biomass. Halcrow et al. (1973) also estimated that $20 \mathrm{~km}^{2}$ of the sea bed sediment was contaminated with trace metals.

In 1985, the recovery of this area of sea bed was investigated by re-surveying the stations sampled by Topping \& McIntyre (1972) for benthic community analysis and sediment trace metal concentrations. This survey was carried out using the same benthic sampling techniques, and in addition, a further 5 stations were sampled in 1985 for trace metal concentrations in the sediment. The results of the macrobenthic community studies are given in this paper, whilst the trace metal concentrations and geochemistry are presented in Rodger et al. (1991; companion paper) and Rodger \& Davies (1991) respectively.

\section{METHODS}

At each station previously sampled by Topping \& McIntyre (1972) (Stns 1 to 5; Fig. 1 of Rodger et al. 1991), two $0.1 \mathrm{~m}^{2}$ van Veen grab and two Craib corer (Craib 1965) samples were taken in March 1985 from FRV 'Scotia'. At the additional stations (6 to 10) only core samples were obtained. As in 1971, the grab samples were washed through $500 \mu \mathrm{m}$ mesh sieves and 
the residue preserved in $10 \%$ formalin. In the laboratory, the macrofauna was extracted by hand, identified to species where possible, enumerated and weighed (blotted wet weight). From these basic data (number of species present, abundance and biomass), the Shannon-Wiener index of diversity using natural logs (Shannon \& Weaver 1963) and the Heip index of evenness (Heip 1974) were calculated. Log-normal distributions were calculated using the technique devised by Gray \& Mirza (1979) with the probit modification proposed by Gray \& Pearson (1982). The general applicability of this descriptive model has been the subject of some debate, since many community estimates appear not to exhibit log-normal distributions. However, the data available in this study are too limited to allow the useful application of more complex analytical techniques, and the approach adopted is considered adequate for the relatively straightforward descriptive comparison made below.

One Craib core from each station (1 to 10) was analysed for redox potential using the technique outlined in Pearson \& Stanley (1979). The upper $8 \mathrm{~cm}$ of the second core was sectioned at $1 \mathrm{~cm}$ intervals, and stored frozen $\left(-20^{\circ} \mathrm{C}\right)$ prior to trace metal analysis in the laboratory (Rodger et al. 1991, Rodger and Davies 1991). Organic carbon levels in sediments from Stns 1 to 5 were estimated by a combination of the wet ashing technique, as outlined in Strickland \& Parsons (1972). with the titrimetric analysis of Menzel (1966).

\section{RESULTS}

\section{5 survey}

Analysis of the macrobenthos from the 5 stations sampled yielded a total of 123 species/taxa (Table 1) and 4870 individuals. The number of species present ranged from 44 at Stn 3 to 64 at Stn 2, with mean densities ranging from 910 ind. $\mathrm{m}^{-2}$ at Stn 3 to 18145 $\mathrm{m}^{-2}$ at $\mathrm{Stn} 5$. The mean biomass varied between $27.94 \mathrm{~g}$ $\mathrm{m}^{-2}$ at Stn 4 and $108.09 \mathrm{~g} \mathrm{~m}^{-2}$ at Stn 5 .

The fauna at all stations was dominated by polychaetes, which accounted for a mean of $54 \%$ of the total abundance, and $45 \%$ of the biomass. The other elements of the fauna showed very variable contributions to the total abundances (Table 2). Up to $47 \%$ of the total abundance at Stns 1 to 4 consisted of the top 5 species (Table 3 ). At $\operatorname{Stn} 5$, the top 5 species grouping accounted for $81 \%$ of the abundance, which is reflected in the depressed Shannon-Wiener diversity and Heip evenness indices in comparison with the other 4 stations (Table 4 ).

The log-normal distributions of the species (Fig. 1) showed good agreement between the 2 samples at each station. In 1985 samples from Stns 1 to 4 had only a few geometric classes represented and exhibited a steep slope to the line, but the absence of representatives of class VII (32 to 63 ind. $\mathrm{m}^{-2}$ ) and class VIII (64 to 127 ind. $\mathrm{m}^{-2}$ ) geometric groups at $\operatorname{Stn} 5$ caused the data to exhibit a broken line ('dog-leg'; i.e. change of slope).

The redox profiles for Stn 1 to 10 in 1985 (Fig. 2) showed a gradation from less reducing conditions at Stns $1,3,4,6,7$ and 10 , to more reducing conditions, particularly at depth, at Stns 2, 5, 8 and 9. The redox potential at Stns 1, 3 and 4 did not fall below $0 \mathrm{mV}$ within the top $10 \mathrm{~cm}$ of the cores. Where present, the redoxcline (Bagander \& Niemisto 1978) was shallowest ( 1 to $2.5 \mathrm{~cm}$ ) at Stns 2 and 5, and deepest (>4 cm) at Stn 6. Stn 2 showed low redox values between 4 to $6 \mathrm{~cm}$ depth and Stn 8 exhibited the most reducing conditions, with a value of $-230 \mathrm{mV}$ at a depth of $10 \mathrm{~cm}$.

The organic carbon concentrations (Fig. 3) in surface sediment $(0$ to $2 \mathrm{~cm}$ ) for Stns 1 to 5 were between 2 and $3 \%$. At Stn 5, concentrations decreased with depth to $1.5 \%$ at $8 \mathrm{~cm}$, whilst at Stn 2 levels showed a marked increase with depth from $3 \%$ at the surface to $5 \%$ at 4 to $6 \mathrm{~cm}$, with a slight decrease with depth thereafter to $4.5 \%$. Stns 1,3 and 4 showed no significant change from surface to a depth of $8 \mathrm{~cm}$.

\section{1 survey}

In order to make comparisons between stations sampled in 1971 and 1985, it was necessary to re-analyse the original disaggregated data, which was presented in summarised form by Topping \& McIntyre (1972). It should be noted that the faunal analysis of the 1971 samples was not as rigorous as that undertaken in 1985 , and certain groups were not separated, e.g. Capitellidae and Cirratulidae were identified only to family level.

In 1971, a total of 48 species/taxa were found at the 5 stations sampled, with a maximum contribution of 35 species at $\operatorname{Stn} 4$, and a minimum of 13 at Stn 3. Total abundances (Table 5) ranged from 32.90 ind. $\mathrm{m}^{-2}$ at Stn 4 to $52500 \mathrm{~m}^{-2}$ at $\operatorname{Stn} 3$, and biomasses from $30.14 \mathrm{~g} \mathrm{~m}^{-2}$ (Stn 1) to $162.71 \mathrm{~g} \mathrm{~m}^{-2}$ (Stn 3). These values were derived from a single sample taken at each station With the exception of Stn 4, the data from individual samples in 1985 showed consistently higher numbers of species. Similarly the total species complement in 1985 was much greater than might have been expected if duplicate samples had been taken in 1971. At Stn 4 , the number of species, diversity and evenness were similar in 1971 and 1985.

The fauna in 1971 (as in 1985) was dominated by annelids. However, unlike 1985 the grouping of the top 
Table 1. Species list of benthic macrofauna for the Garroch Head old dump site, Stns 1 to 5, 1985. Taxonomic order within phyla according to Howson (1987). Suffixes as per Pearson et al. (1986)

\section{Polychaeta}

Aphrodita aculeata (juv.)

Enipo kinbergi

Harmothoe sp.

Harmothoe antilopes

Harmothoe castanea

Pholoe inornata

Pholoe sp.

Phyllodoce laminosa

Anaitides mucosa/maculata

Dentanaitis subulifera

Eulalia viridis

Eteone longa

Glycera alba

Glycinde nordmanni

Goniada maculata

Shaerodorum gracilis

Gyptis roseus

Kefersteinia cirrata

Ophiodromus flexuosus

Ancistrosyllis groenlandica

Synelmis klatti

Nereis longissima

Nephtys cirrosa

Nephtys hombergii

Nephtys hystricis

Lumbrineris fragilis

Lumbrineris gracilis

Lumbrineris tetraura

Ophryotrocha hartmanni

Eunicidae (juv.)

Scoloplos armiger

Levensenia gracilis

Paradoneis lyra

Apistobranchus tullbergi

Poecilochaetus serpens

Minuspio cirrifera

Prionospio malmgreni

Pseudopolydora ef paucibranchiata

Scolelepis (Parascolelepis) tridentata

Spiophanes kroyeri

Chaetozone setosa

Cirriformia sp.

Tharyx marioni

Tharyx multibranchis

Tharyx sp

Raricirrus sp.

Diplocirrus glaucus

Capitellidae (indet)

Capitella capitata

Dasybranchus caducus

Mediomastus sp

Notomastus latericeus

Rhodine loveni

Ophelina acuminata

Polyphysia crassa

Scalibregma inflatum

$(\cdot+)$

Myriochele oculata

Amphictene auricoma

Melinna cristata

Anobothrus gracilis

Eclysippe sp.

Terebellidae

Terebellides stroemi

Pista cristata
Lysilla loveni

Polycirrus sp.

Jasminiera caudata

Oligochaeta

Tubificoides benedeni

Oligochaete (indet.)

Mollusca

Chaetoderma nitidulum

Lunatia poliana

Cylichna cylindracea

(o)

Philine scabra

Philine sp.

Gastropod A

Gastropod B

Nucula sulcata

Nucula tenuis

Myrtea spinifera

Thyasira flexuosa

Tellimya ferruginosa

Acanthocardia echinatum

Parvicardium minimum

Spisula sp.

Abra sp.

Abra alba

Abra nitida

Arctica sp. (juv.)

Hiatella arctica

Corbula gibba

Bivalve A

\section{Crustacea}

Balanus nauplius

Ostracoda

Tanaidacea

Amphipod A

Amphipod B

Amphipod C

Ampelisca sp.

Ampelisca gibba

Eriopisa elongata

Cumacean A

Iphinoe $\mathrm{sp}$

Eudorella truncatula

Leucon nasica

Diastyllis lucifera

Diastyllis rathkei

Euphausidae

Nephrops norvegica

Calocaris macandraea

Zooea

\section{Echinodermata}

Ophiuroidea (juv.)

Amphiura chiajei

Amphiura filiformis

Ophiura affinis

\section{Others}

Priapuliae

Nematoda

Nemertea

Cerianthus sp.

(o) Listed as species having high dominance in Clyde Sea area

(*) Listed as species indicative of enrichment on the Garroch Head site

$(+)$ Listed as species indicative of enrichment on a variety of grounds 
Table 2. Summary of abundance and biomass of the benthic macrofauna at Garroch Head old dump site, Stns 1 to 5, 1985.1 and 2 refer to samples

\begin{tabular}{|c|c|c|c|c|c|c|c|c|c|c|}
\hline & \multicolumn{2}{|c|}{$\operatorname{Stn} 1$} & \multicolumn{2}{|c|}{ Stn 2} & \multicolumn{2}{|c|}{$\operatorname{Stn} 3$} & \multicolumn{2}{|c|}{ Stn 4} & \multicolumn{2}{|c|}{$\operatorname{Stn} 5$} \\
\hline & 1 & 2 & 1 & 2 & 1 & 2 & 1 & 2 & 1 & 2 \\
\hline \multicolumn{11}{|c|}{ Abundance (ind. $\mathrm{m}^{-2}$ ) } \\
\hline Polychaeta & 880 & 100 & 1090 & 1290 & 540 & 570 & 770 & 680 & 13550 & 4490 \\
\hline Oligochaeta & - & - & 50 & - & - & - & 50 & 30 & 4330 & 980 \\
\hline Mollusca & 420 & 270 & 490 & 490 & 130 & 120 & 150 & 130 & 880 & 560 \\
\hline Crustacea & 30 & 20 & 40 & 40 & 20 & 10 & 160 & 30 & 120 & 10 \\
\hline Echinodermata & 140 & 30 & 40 & 40 & 60 & 130 & 110 & 10 & 700 & 190 \\
\hline Others & 190 & 160 & 210 & 210 & 80 & 160 & 190 & 90 & 5110 & 5370 \\
\hline Total & 1660 & 1480 & 2320 & 2070 & 830 & 990 & 1430 & 970 & 24690 & 11600 \\
\hline \multicolumn{11}{|c|}{ Wet weight $\left(\mathrm{g} \mathrm{m}^{-2}\right)$} \\
\hline Polychaeta & 28.102 & 47.441 & 13.967 & 22.761 & 16.550 & 10.941 & 20.303 & 16.616 & 36.516 & 17.127 \\
\hline Oligochaeta & - & - & 0.025 & - & - & - & 0.011 & 0.002 & 0.867 & 0.162 \\
\hline Mollusca & 39.574 & 36.115 & 23.320 & 17.771 & 13.850 & 5.979 & 1.185 & 6.202 & 48.841 & 57.925 \\
\hline Crustacea & 0.233 & 0.156 & 0.149 & 0.043 & 9.143 & 0.002 & 10.290 & 0.149 & 0.536 & 0.001 \\
\hline Echinodermata & 0.296 & 0.006 & 0.010 & 0.008 & 8.866 & 1.686 & 0.012 & 0.003 & 5.987 & 0.292 \\
\hline Others & 0.395 & 0.421 & 0.098 & 7.822 & 0.070 & 0.451 & 0.940 & 0.173 & 33.450 & 14.469 \\
\hline Total & 68.800 & 84.139 & 37.569 & 48.405 & 48.479 & 19.059 & 32.741 & 23.145 & 126.197 & 89.976 \\
\hline
\end{tabular}
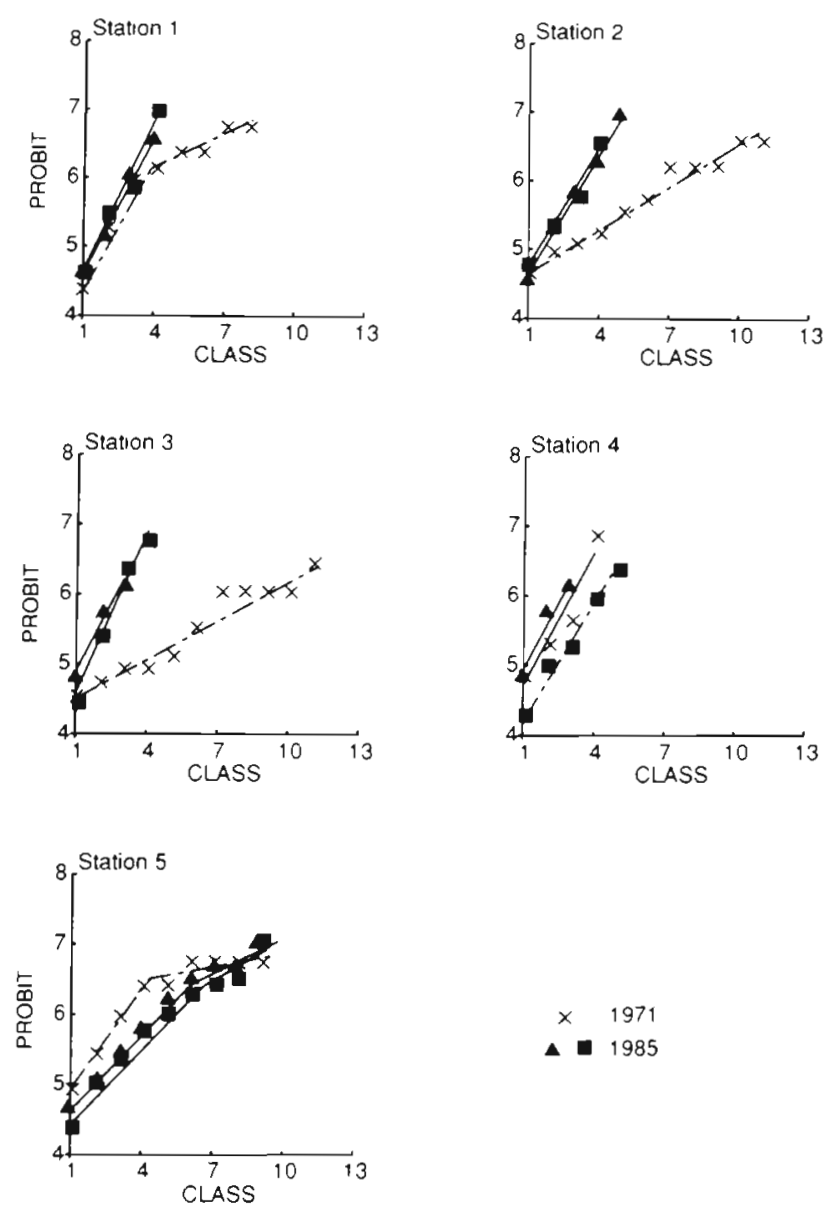

Fig. 1 Log-normal (Gray \& Mirza 1979) plots of fauna from Stns 1 to 5 for 1985, also showing 1971 data from Topping \& McIntyre (1972)
5 species (Table 3) shows that the opportunist polychaetes Capitellidae and Peloscolex (Tubificoides) $\mathrm{sp}$. accounted for a very large proportion of the total abundance in 1971, especially at Stns 2 and 3 (93 and $94 \%$ respectively). Only 2 species of mollusc were represented in the top 5 ranking (Thyasira flexuosa and Nucula turgida) and, with the exception of the Nemertea, the remainder were annelids. No crustaceans were present in the top 5 grouping and only a few specimens were taken overall. Echinoderms were represented only by an occasional juvenile ophiuroid. In 1985, the fauna was much more diverse, and less dominated by opportunist species.

The log-normal distributions (Fig. 1) suggest that, with the exception of Stn 4, the 1971 stations exhibited either a dog-leg condition or a shallow gradient. They also had a larger number of geometric classes present than the more 'normal' community at Stn 4. The absence of representatives of classes V and VI, or VII to X, accounted for the dog-leg and shallow gradient conditions respectively.

\section{DISCUSSION}

In attempting to make comparisons between a limited number of stations sampled on only 2 occasions 14 yr apart, the authors recognise that vigorous statistical analysis is not possible, and that reliance has been placed upon descriptive techniques and faunal indices. In support of this approach, it may be noted that at Stn 4 (least affected by the disposal operation) there was 


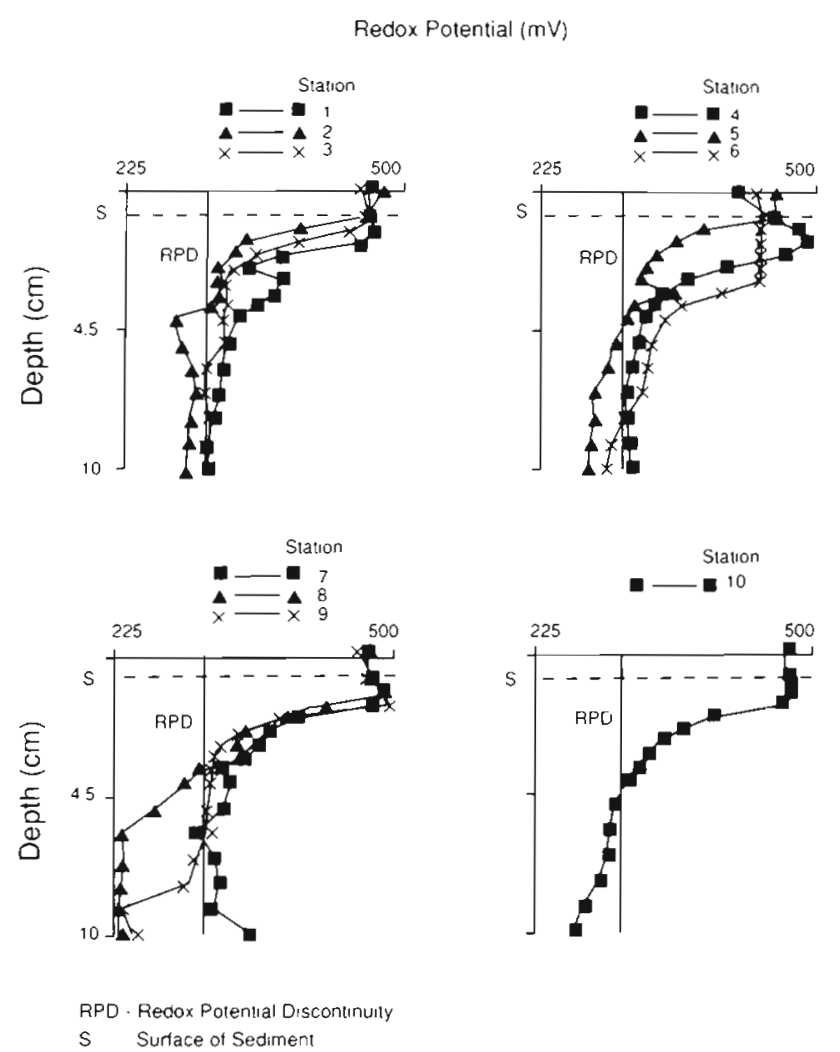

Fig. 2. Profiles of redox potential in the sediment from Stns 1 to 10 at the pre-1974 dump site

good agreement between the 1971 and 1985 faunal indices and log-normal distribution patterns. Movement to the new disposal site had no noticeable impact on the fauna at this station, and redox values remained positive throughout the upper $10 \mathrm{~cm}$ of sediment. This suggests that differences at other stations may reflect real changes in the benthic communities. Pearson et al. (1986) studied the composition of macrobenthic communities in the Clyde Sea area and concluded that the area was generally enriched due to high nutrient inputs, particularly to the Arran/Ayrshire basin. Localised waste disposal contributed to the high carbon input, and species indicative of organically enriched sediments would therefore be present naturally (see Table 1).

In 1971, 4 stations (1, 2, 3 and 5) had very modified communities, as indicated by the diversity and evenness indices. By 1985, the faunal indices at Stns 1 to 4 had returned to values similar to those exhibited by communities from similar sediment types in the Clyde but remote from the dumping site. Although some of the species found, e.g. Capitella capitata and Chaetozone setosa, are considered as indicative of organic enrichment, they were present in relatively low numbers.

The diversity and evenness indices at Stn 5 (Table 4) showed a marked improvement between 1971 and 1985 , but the community continued to show the lowest diversity and evenness, despite the presence of a high total number of species. Twenty-one species occurred exclusively at this station in 1985 and the fauna contained representatives of all the characteristic groupings suggested by Pearson et al. (1986) as being present in a gradation over the sludge dumping grounds (see Table 1). Although insufficient stations were sampled in 1985 to be able to establish detailed gradients of effect in the manner suggested by Pearson \& Rosenberg (1978), Stn 5 may represent a transition zone between the now slightly enriched area at the pre-1974 disposal area, and the heavily enriched present disposal site.

The dog-leg condition in log-normal plots has been associated (Gray \& Mirza 1979) with communities in transition through stress. Lines with a shallow slope, covering a large number of geometric groups, are considered to represent stressed communities which are in equilibrium, and steeply sloping lines, with few geometric classes, represent unstressed equilibrium communities. The log-normal distributions of the 1971 data suggest that the communities at Stns 2 and 3 were

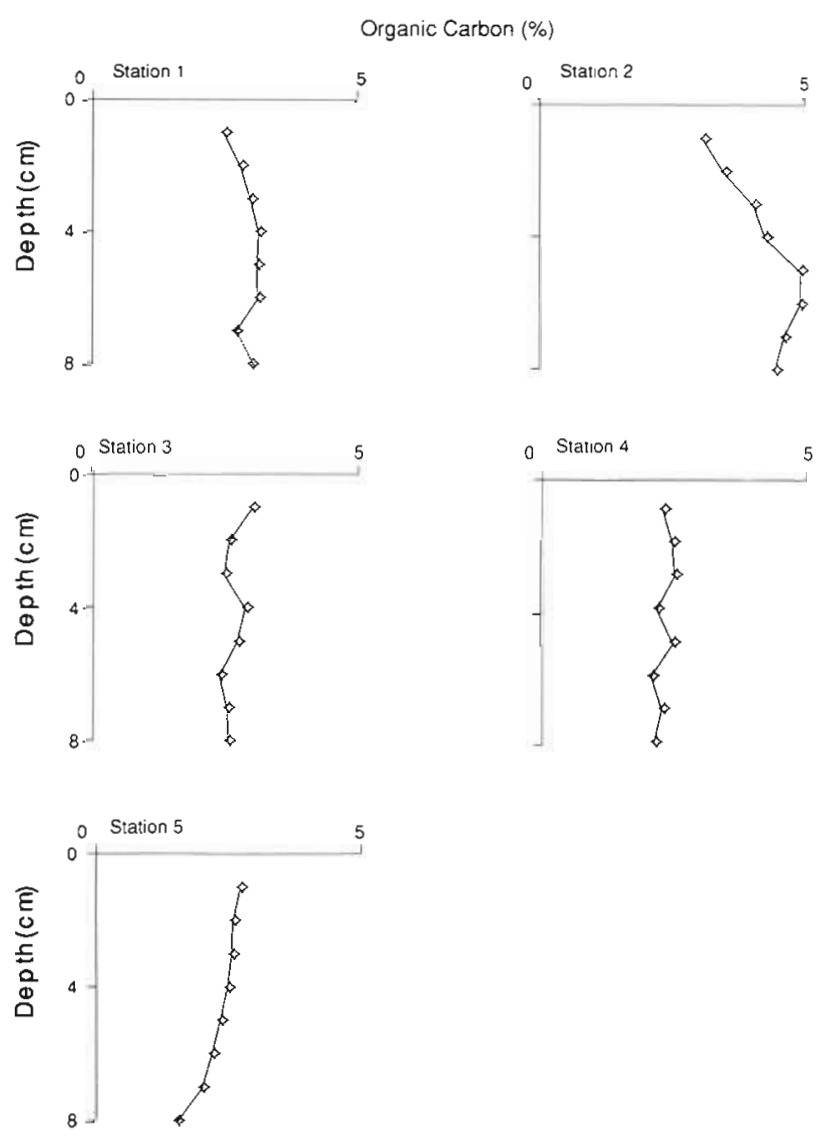

Fig. 3. Concentrations of organic carbon $(\%)$ in the sediment from Stns 1 to 5 at the pre-1974 dump site 
Table 3. Top 5 species dominance lists for Garroch Head old dump site, Stns 1 to 5, 1971 (Topping \& McIntyre 1972 ) and 1985. Cum. $\%$ cumulative percentage of total abundance at each site

\begin{tabular}{|c|c|c|c|c|c|}
\hline \multirow[t]{2}{*}{1971} & & & \multicolumn{3}{|c|}{1985} \\
\hline & Ind. $\mathrm{m}^{-2}$ & Cum. \% & & Ind. $m^{-2}$ & Cum. \% \\
\hline \multicolumn{6}{|c|}{ Station 1} \\
\hline Capitellidae & 3170 & 67.88 & Nemertea & 160 & 10.03 \\
\hline Eunicidae (juv.) & 680 & 82.44 & Chaetozone setosa & 130 & 18.18 \\
\hline Nemertea & 240 & 87.58 & Abra alba & 115 & 25.39 \\
\hline Paraonis gracilis (Levensenia) ${ }^{\circ}$ & 80 & 89.39 & Spiophanes kroyeri & 105 & 31.97 \\
\hline Nucula turgida & 70 & 90.78 & Prionospio malmgreni & 85 & 37.30 \\
\hline \multicolumn{6}{|c|}{ Station 2} \\
\hline Peloscolex sp. & 32550 & 77.37 & Spiophanes kroyeri & 270 & 12.24 \\
\hline Capitellidae & 6520 & 92.87 & Thyasira flexuosa & 235 & 22.90 \\
\hline Audouinia sp. (Cirriformia). & 970 & 95.18 & Chaetozone setosa & 140 & 29.25 \\
\hline Cirratulidae & 820 & 97.12 & Nemertea & 130 & 35.15 \\
\hline Cirratulus sp. & 570 & 98.48 & Nuculoma tenuis & & \\
\hline & & & $\begin{array}{l}\text { Nucula sulcata } \\
\text { Mediomastus sp. }\end{array}$ & 115 & 40.36 \\
\hline \multicolumn{6}{|c|}{ Station 3} \\
\hline Peloscolex sp. & 31670 & 60.32 & Spiophanes kroyeri & 115 & 12.64 \\
\hline Capitellidae & 17740 & 94.11 & Nemertea & 95 & 23.08 \\
\hline Eunicidae (juv.) & 1100 & 96.21 & Minuspio cirrifera & 80 & 31.87 \\
\hline Cirratulidae & 820 & 97.77 & Ophiuroidea & 80 & 40.66 \\
\hline Cirratulus sp. & 540 & 98.90 & Nephtys hystricis & 60 & 47.25 \\
\hline \multicolumn{6}{|c|}{ Station 4} \\
\hline Chaetozone setosa & 590 & 17.93 & Tharyx marioni. & 250 & 12.50 \\
\hline Capitellidae & 350 & 28.93 & Minuspio cirrifera & 130 & 23.33 \\
\hline Diplocirrus glaucus & 350 & 39.57 & Spiophanes kroyeri & 105 & 32.08 \\
\hline Paraonis gracilis (Levensenia) & 240 & 46.51 & Nemertea & 90 & 39.58 \\
\hline Eunicidae (juv.) & 200 & 52.58 & Levensenia gracilis & 60 & 45.42 \\
\hline \multicolumn{6}{|c|}{ Station 5} \\
\hline Capitellidae & 8370 & 89.14 & Mediomastus sp. & 5185 & 28.58 \\
\hline Scolelepis fuliginosa & 370 & 93.08 & Nematoda & 5185 & 57.06 \\
\hline Nemertea & 130 & 94.46 & Oligochaeta (indet.) & 2335 & 69.90 \\
\hline Chaetozone setosa & 100 & 95.53 & Capitella capitata & 1445 & 77.85 \\
\hline Lumbrinereis $\mathrm{sp}$. & & & Ophryotrocha hartmanni & 610 & 81.21 \\
\hline Paraonis gracilis (Levensenia) ${ }^{*}$ & 50 & 96.06 & & & \\
\hline Thyasira flexousa & & & & & \\
\hline - Synonym (after Howson 1987) & & & & & \\
\hline
\end{tabular}

severely stressed but in equilibrium and that Stns 1 and 4 were in a transitional state. The 1985 plots, however, suggest that the communities at Stns 1 to 4 have returned to equilibrium unstressed conditions, but that Stn 5 continues to exhibit transitional characteristics.

The increase in diversity in the fauna since dumping of sewage sludge ceased has been accompanied by decreases in the organic carbon content in surface ( 0 to $1 \mathrm{~cm}$ ) sediments, consistent with a reduction of the input of sludge, increased importance of natural sedimentation and possibly continuing mineralisation of sewage solids. The presence of elevated organic carbon and trace metal concentrations at depth in Stn 2 (Rodger et al. 1991) suggests the persistence of historical contamination by sewage sludge in these subsurface sediments.

There has been an obvious improvement in the status of the communities at the 4 stations strongly impacted in 1971 as assessed by the various community indices, consistent with the changes in sediment organic carbon and redox potentials. The individual sample abundance and biomass has returned to levels typical of the slightly enriched environment of the Clyde. Only Stn 5 showed any effects of sludge input, and this may be 
Table 4. Shannon-Wiener (SW) and Heip indices of diversity and evenness for Garroch Head old dump site, Stns 1 to 5, 1971 (Topping \& McIntyre 1972) and 1985

\begin{tabular}{|c|c|c|c|c|}
\hline & \multirow[t]{2}{*}{1971} & \multicolumn{3}{|c|}{1985} \\
\hline & & Sample 1 & Sample 2 & Total \\
\hline \multicolumn{5}{|l|}{ Station 1} \\
\hline No species & 23 & 42 & 34 & 51 \\
\hline SW index & 1.300 & 3.315 & 3.127 & 3.412 \\
\hline Heip index & 0.121 & 0.647 & 0.661 & 0.586 \\
\hline \multicolumn{5}{|l|}{ Station 2} \\
\hline No. species & 17 & 51 & 40 & 64 \\
\hline SW index & 0.802 & 3.408 & 3.087 & 3.402 \\
\hline Heip index & 0.077 & 0.584 & 0.536 & 0.461 \\
\hline \multicolumn{5}{|l|}{ Station 3} \\
\hline No. species & 13 & 24 & 31 & 44 \\
\hline$S W$ index & 0.932 & 2.793 & 3.037 & 3.242 \\
\hline Heip index & 0.128 & 0.666 & 0.661 & 0.572 \\
\hline \multicolumn{5}{|l|}{ Station 4} \\
\hline No. species & 35 & 32 & 32 & 46 \\
\hline SW index & 2.941 & 2.995 & 3.062 & 3.215 \\
\hline Heip & 0.527 & 0.613 & 0.657 & 0.531 \\
\hline \multicolumn{5}{|l|}{ Station 5} \\
\hline No. species & 24 & 52 & 47 & 63 \\
\hline SW index & 0.601 & 2.182 & 1.971 & 2.201 \\
\hline Heip index & 0.036 & 0.154 & 0.134 & 0.130 \\
\hline
\end{tabular}

Table 5. Summary of abundance, biomass, diversity and evenness indices of benthic macrofauna at Garroch Head, old dump site, Stns 1 to 5. Data from Topping \& McIntyre (1972)

\begin{tabular}{|c|c|c|c|c|c|}
\hline & \multicolumn{5}{|c|}{ Station } \\
\hline & 1 & 2 & 3 & 4 & 5 \\
\hline \multicolumn{6}{|c|}{ Abundance (ind. $\mathrm{m}^{-2}$ ) } \\
\hline Polychaeta & 4220 & 9550 & 20820 & 2610 & 9120 \\
\hline Oligochaeta & 20 & 32550 & 31670 & 120 & - \\
\hline Mollusca & 180 & - & - & 270 & 110 \\
\hline Crustacea & - & - & - & 20 & 60 \\
\hline Echinodermata & - & 10 & - & 10 & - \\
\hline Others & 250 & 10 & 10 & 240 & 140 \\
\hline Total & 4670 & 42070 & 52500 & 3270 & 9430 \\
\hline \multicolumn{6}{|c|}{ Wet weight biomass $\left(\mathrm{g} \mathrm{m}^{-2}\right.$ ) } \\
\hline Polychaeta & 15.419 & 40.091 & 102.157 & 82.583 & 37.922 \\
\hline Oligochaeta & 0.010 & 56.683 & 56.000 & 0.073 & - \\
\hline Mollusca & 12.030 & - & - & 12.365 & 12.434 \\
\hline Crustacea & - & - & - & 0.060 & 0.110 \\
\hline Echinodermata & - & 0.010 & - & 0.010 & - \\
\hline Others & 2.679 & 0.010 & 4.550 & 2.679 & 1.445 \\
\hline Total & 30.138 & 96.794 & 162.707 & 97.770 & 51.911 \\
\hline
\end{tabular}

attributable to the marginal effects of the current disposal operation.

In part the improvement in the macrobenthic communities parameters may be an artefact of improvements in the faunal analysis but the similarity between the 1985 and 1971 data for Stn 4 shows that this factor is of minor importance and alone cannot account for the gross changes observed in the community statistics. Warwick (1988) has shown that similar trends can be recognised in faunal data analysed at various tax- 
onomic levels, suggesting that the apparent recovery of the fauna at the old Garroch Head disposal site may be considered as a reliable reflection of the resilience of the marine environment.

Acknowledgements. The authors thank the officers and crew of FRV 'Scotia' for assistance with sampling, and Drs I. $M$. Davies and G. Topping (SOAFD), for discussion and critical review of this paper.

\section{LITERATURE CITED}

Bagander, L. E., Neimisto, L. (1978). An evaluation of the use of redox measurements for characterising recent sediments. Estuar. coast. mar. Sci. 6: 127-134

Craib, J. S. (1965). A sampler for taking short undisturbed marine cores. J. Cons. perm. int. Explor. Mer 30 (1): 34-39

Devine, M., Simpson, D. (1985). Impact of and recovery from sewage sludge dumping at the Philadelphia dumpsite. NOAA Tech. Mem. NOS OMA 15: $37 \mathrm{pp}$

Dooley, H. D. (1979). Factors influencing water movements in the Firth of Clyde. Estuar coast. mar. 9: 631-641

Eleftheriou, A., Moore, D. C., Basford, D. J., Robertson, M. R. (1982). Underwater experiments of the effects of sewage sludge on a marine ecosystem. Neth. J. Sea Res. 16: $465-473$

Gray, J., Mirza, F. B. (1979). A possible method for the detection of pollution induced disturbance on marine benthic communities. Mar. Pollut. Bull. 10: 142-146

Gray, J., Pearson, T H. (1982). Objective selection of sensitive species indicative of pollution induced change in benthic communities. I. Comparative methodology. Mar Ecol. Prog. Ser. 9: 111-119

Halcrow, W., Mackay, D. W., Thornton, I. (1973). The distribution of heavy metals and fauna in the Firth of Clyde in relation to the disposal of sewage sludge. J. mar. biol. Ass. U.K. 53: 721-739

Harper, E., Greer, W. T (1988). Marine disposal of sewage sludge by North West Water Authority and Strathclyde Regional Council. In: Marine treatment of sewage and sludge. Proceedings of a conference held by the Institute of Civil Engineers, Brighton 1987. Thames Telford, London, $137-152$

This article was submitted to the editor
Heip, C. (1974). A new index measuring evenness. J. mar. biol. Ass. U.K. $54: 555-557$

Howson, C. M. (ed.) (1987). Species directory to the British marine fauna and flora. Marine Conservation Society, Ross-on-Wye

Mackay, D. W., Halcrow, W., Thornton, I. (1972). Sludge dumping in the Firth of Clyde. Mar. Pollut. Bull. 3: 7-10

Mackay, D. W., Topping, G. (1970). Preliminary report on the effects of sludge disposal at sea. Effl. Wat. Treat. J., November: 641-649

Menzel, D. W (1966). Particulate organic carbon in the deep sea. Deep Sea Res. 14: 229-238

Pearson, T. H. Ansell, A. D., Robb, L. (1986). The benthos of the deeper sediments of the Firth of Clyde, with particular reference to organic enrichment. Proc. R. Soc. Edinb. 90: 329-350

Pearson, T H., Rosenberg, R. (1978). Macrobenthic succession in relation to organic enrichment and pollution of the marine environment. Oceanogr. mar. Biol. A. Rev. 16: 229-311

Pearson, T H. Stanley, S. O. (1979). Comparative measurement of the redox potential of marine sediments as a rapid means of assessing the effect of organic pollution. Mar. Biol. 53: 371-379

Rodger, G. K., Davies, I. M. (1991). The recovery of a sewage sludge dumping ground. Trace metal geochemistry. Sci. Total Environ. (in press)

Rodger, G. K., Davies, I. M., Moore, D. C. (1991). The recovery of a sewage sludge dumping ground. I. Trace metal concentrations in the sediment. Mar. Ecol. Prog. Ser. 75: 293-299

Shannon, C. E., Weaver, W. (1963). The mathematical theory of communication. University of Illinois Press, Urbana

Strickland, J. D. H., Parsons, T. R. (1972). A practical handbook of sea water analysis. Bull. Fish. Res. Bd Can. 167: $1-311$

Topping, G. (1987). Sewage sludge dumping in Scottish waters: current practices and future outlook. The Public Health Engineer 14 (b) 49-51

Topping, G., McIntyre, A. D. (1972). Benthic observations on a sewage sludge dumping ground. Int. Counc. Explor Sea Comm. Meet. ICES/E: 30

Warwick, R. M. (1988). Analysis of community attributes of the macrobenthos of Frierfjord/Langesundfjord at taxonomic levels higher than species. Mar. Ecol. Prog. Ser. 46: $167-170$

Manuscript first received: August 28, 1990

Revised version accepted: June 17, 1991 